August 2002

\title{
Parallel Imports and the Japan Fair Trade Commission
}

\author{
David Flath* \\ North Carolina State University \\ and \\ Tatsuhiko Nariu** \\ Kyoto University (Graduate Faculty of Economics)
}

\begin{abstract}
We review the facts pertaining to some recent antimonopoly cases in Japan involving interference with unauthorized imports, so-called parallel imports, and propose economic explanations for the behavior of the foreign manufacturers in these cases. The intellectual property law of Japan provides a mechanism for private obstruction of parallel imports but under the antimonopoly law of Japan as implemented by the Japan Fair Trade Commission such obstruction is per se illegal. To the extent that price discrimination is the rationale for obstruction of parallel imports the JFTC policy has promoted lower prices and increased economic welfare in Japan. But we argue that in several of the cases we examine the rationale for obstructing parallel imports was to preserve incentives for distributors to invest and innovate and to preserve efficient marketing arrangements that depended upon resale price maintenance.
\end{abstract}

Flath was supported by a grant from the Abe Fellowship Program of the Social Science Research Council and the American Council of Learned Societies with funds provided by the Japan Foundation Center for Global Partnership.

* David Flath

Department of Economics

North Carolina State University

Raleigh, NC 27695-8110

USA

E-mail.david_flath@ncsu.edu

**Tatsuhiko Nariu

Graduate Faculty of Economics, Kyoto University

Yoshida-Honmachi, Sakyo-ku, Kyoto 606-8501

JAPAN.

Tel. +81-75-753-3481

E-mail.nariu@econ.kyoto-u.ac.jp 


\section{Parallel Imports and the Japan Fair Trade Commission}

\section{Introduction}

This paper seeks to accomplish two things. First, we review the facts pertaining to some recent antimonopoly cases in Japan involving interference with unauthorized imports, so-called parallel imports, and propose economic explanations for the behavior of the foreign manufacturers in these cases. In doing this we tie existing theoretical explanations for sole import agent contracts to some actual cases, and also suggest some novel explanations not so far evident in the theoretical literature. Second, we assess the policy of the government authorities in these cases from the standpoint of Japan's national welfare. We argue that some of the cases promoted the national welfare of Japan but that others did not.

Parallel imports, sometimes called gray imports, are imports of genuine goods without the authorization of the trademark owner. A manufacturer that is unable to block or deter parallel imports is unable to establish a national market as an exclusive sales territory for its designated distributors. From the standpoint of national welfare this might be a good thing or not, depending upon the rationale of the manufacturer. If the manufacturer's obstruction of parallel imports is part of a scheme for price discriminating across nations, then policies that upset that will promote lower prices locally and increase national welfare, even though they lower the profits of the foreign manufacturer and raise prices in other nations, a simple point cogently argued by Richardson (2002). But there are reasons other than price discrimination for manufacturers to obstruct parallel imports. As we argue below, a distributor that is a sole agent, in effect a monopolistic wholesaler of the particular brand, has a stronger economic incentive to undertake promotional investments and a stronger incentive to seek cost reducing innovations than would an industry of competing distributors. To preserve these incentives to invest and innovate will require that the foreign supplier can effectively obstruct parallel imports. Obstruction of parallel imports may also be necessary to maintain the effectiveness of marketing systems that depend upon vertical restraints such as resale price maintenance or exclusive territory systems. Vertical restraints have been the subject of antitrust litigation in the US, Japan and elsewhere. A preoccupation of the government authorities in these cases is the possibility that vertical restraints might be part of a scheme for cartelizing a market. And in a few cases they have been shown to be precisely that. See for example the Flath (1989) discussion of the Tokyo Kokuyo Kai case, Auto Glass case and Powdered Milk cases. But in the preponderance of cases the rationale for vertical restraints is to avoid marketing problems associated with opportunistic behavior and free-riding by competing distributors of the same brand. Where parallel imports upset these sorts of vertical restraints, government policies that promote parallel imports will raise distribution costs and lower national welfare. It is evident that neither blanket tolerance of parallel imports nor uniform hostility towards them is likely to attain a first-best. On these grounds Gallini and Hollis (1999) argue for a policy regime in which trademark protection neither precludes nor sanctions parallel imports and leaves it to antitrust law to determine on a caseby-case basis whether private obstruction of parallel imports is to be allowed.

Japan has a policy regime that resembles the one recommended by Gallini and Hollis in an important respect. Its intellectual property law neither precludes nor sanctions parallel imports. But under the antimonopoly law of Japan private obstruction of parallel imports is per se illegal, not subject to a rule of reason. We will review several recent cases before the Japan Fair Trade 
Commission (JFTC), the agency of the Japanese government charged with enforcing the antimonopoly law. In a couple of the cases-involving pianos and ice cream-the private obstruction of parallel imports seems to have been to prevent international arbitrage from interfering with price discrimination. Here the per se rule against private obstruction of parallel imports probably promoted the national welfare of Japan by lowering import prices. But in other cases-involving water purification devices, handbags, chinaware, athletic shoes, and trading cards-the private obstruction of parallel imports was motivated at least in part by the desire to promote investments by distributors or to preserve efficient marketing practices and deter free-riding.

We begin by reviewing the relevant theories and then turn to the cases themselves.

\section{Reasons Why Suppliers of Branded Merchandise Would Wish to Block Parallel Imports}

\section{2-1. Price discrimination}

A monopoly that sells in segmented markets will enrich itelf if it can set prices that maximize profit in each market separately. Arbitrage across markets will prevent its pricing in this way and herein is an obvious reason why a firm that sells a branded product in more than one country would want to prevent unauthorized parallel imports-they represent precisely such corrosive arbitrage. There is a vast literature on price discrimination. The special conditions under which price discrimination regimes improve or worsen resource allocation compared to their alternatives are thus well-known.

Consider Stigler's definition of price discrimination:

$$
\mathrm{p}_{\mathrm{i}} / \mathrm{mc}_{\mathrm{i}} \neq \mathrm{p}_{\mathrm{j}} / \mathrm{mc}_{\mathrm{j}}
$$

where $p_{i}$ is the marginal tariff for customer $i$ and $m_{c}$ is marginal cost of supplying $i$. One nice feature of the definition is that it identifies "price discrimination" with a particular sort of misallocation that is distinct from the basic contrived scarcity of monopoly. (Stigler himself noted this fact in George Stigler, The Theory of Price, MacMillan, fifth edition, 1987, p. 210, f.n. 13). That is, price discrimination in the Stigler sense exists if and only if a more valued output could have been produced at the same cost as actually incurred. In the basic monopolistic distortion, insufficient costs are incurred in supplying output (Too little output is produced).

To be more precise, for Stigler, price discrimination does not exist only if the allocation across customers is such as to maximize social welfare given the cost incurred in producing the output. For the two customer case, the non-discriminatory allocation solves:

$$
\underset{\mathrm{q}_{1}, \mathrm{q}_{2}}{\max } \mathrm{W}=\mathrm{V}_{1}\left(\mathrm{q}_{1}\right)-\mathrm{c}_{1}\left(\mathrm{q}_{1}\right)+\mathrm{V}_{2}\left(\mathrm{q}_{2}\right)-\mathrm{c}_{2}\left(\mathrm{q}_{2}\right) \text { s.t. } \mathrm{c}_{1}\left(\mathrm{q}_{1}\right)+\mathrm{c}_{1}\left(\mathrm{q}_{1}\right) \leq \mathrm{C}
$$

where $V_{i}\left(q_{i}\right)$ is the value to customer $i$ of his allocation and $c_{i}$ is the cost of supplying it. The necessary condition for solution is

$$
\left(\mathrm{V}_{\mathrm{i}}^{\prime}-\mathrm{c}_{\mathrm{i}}{ }^{\prime}\right) / \mathrm{c}_{\mathrm{i}}^{\prime}=\lambda, \quad \mathrm{i}=1,2,
$$

where $\lambda$ is the Lagrange multiplier. But each customer chooses his own purchase quantity so as 
to maximize his consumer surplus, given the tariff schedule $\mathrm{T}(\mathrm{q})^{1}$ :

$\max V\left(q_{i}\right)-T\left(q_{i}\right)$

$\mathrm{q}_{\mathrm{i}}$

which requires that $\mathrm{V}_{\mathrm{i}}{ }^{\prime}=\mathrm{T}_{\mathrm{i}}{ }^{\prime}$. Thus we find that the nondiscriminatory allocation attains, only if the tariff schedule is such that

$\mathrm{T}_{\mathrm{i}}{ }^{\prime} / \mathrm{c}_{\mathrm{i}}{ }^{\prime}=1+\lambda, \mathrm{i}=1,2$.

And this matches the Stigler definition of non-discriminatory tariff schedule (non-discriminatory pricing).

An immediate implication is that a regime with price discrimination confers greater social welfare than another, non-discriminatory, monopolistic regime, only if it entails greater output than the non-discriminatory regime. This result has been in the literature for a long time (see for example Schmalensee (1981)) but not tied so directly to the Stigler definition of price discrimination - as far as we are aware. Of course this is only a necessary condition for price discrimination to increase welfare, not sufficient. The effects of price discrimination on global welfare are relevant for evaluating multilateral rules pertaining to parallel imports, the main focus of Malueg and Schwartz (1994). They show that, depending on the dispersion of demand across nations, allowing parallel imports and thus inducing internationally uniform pricing might actually lower world economic welfare. But for the welfare of a single nation, only the effect on its own consumers matters for its policy toward parallel imports of foreign manufacturers. And clearly, allowing parallel imports that exploit arbitrage opportunities in price discrimination across nations can only lower the prices in the target country and benefit its consumers. As Richardson (2002) has argued, this may well explain why countries would unilaterally invite parallel imports, as New Zealand, Australia, Singapore and others have recently done.

By Stigler's definition, a two-part tariff, $\mathrm{T}(\mathrm{q})=\mathrm{A}+\mathrm{pq}$, is not discriminatory (even if the flat fee "A" varies from customer to customer). Also, if customers are identical to one another and confront the same tariff schedule then there is no discrimination, regardless of what the schedule is. And finally, full appropriation of the consumer surplus of all customers- called first degree price discrimination by Pigou- is not discriminatory as defined by Stigler. Maskus and Chen (forthcoming) make the useful point that an arbitrage inducing price difference, and not price discrimination per se, is the crucial premise for parallel imports. So for instance, if a monopolist is indeed setting a two-part tariff, $\mathrm{T}(\mathrm{q})=\mathrm{A}+\mathrm{pq}$, in its sales to wholesalers in each nation this entails arbitrage opportunities across nations, even though it is not price discriminating in the Stigler sense. Such a monopolist would still want to block parallel imports.

\section{Price discrimination and exchange rate pass-through}

A foreign manufacturer might not fully pass through exchange rate movements to import prices. The simplest example of this phenomenon is one in which unit cost is tied to the exchange rate and

${ }^{1}$ Here a tariff schedule is the expenditure needed to purchase each alternative quantity given the menu of prices quoted by the monopolist. For instance, ordinary pricing corresponds to a tariff schedule $\mathrm{T}(\mathrm{q})=\mathrm{pq}$. Nonlinear tariff schedules correspond to multipart pricing and other such complicated pricing regimes. 
the import price is a Bertrand-Nash equilibrium. If the firms in the market supply identical goods then the firm with the lowest unit cost sets price just below the unit cost of its nearest rival and supplies the entire market demand at that price. A fall in unit cost (or possibly a rise in unit cost) of only the leading firm has no effect on the equilibrium price. In the literature on exchange rate pass-through this is referred to as "pricing to market".

The sort of pricing regime in which exchange rate changes are not fully passed through to import prices is discriminatory in the Stigler sense. In other words non pass-through of exchange rate movements exposes the existence of price discrimination across countries. Non pass-through of exchange rates is a corollary of price discrimination and not itself a reason separate from price discrimination why suppliers of branded merchandise would want to block parallel imports. But exchange rate-movements may well increase the profit to an international monopolist from so price discriminating across countries as well as increasing the potential profit from arbitrage. Several authors have noted the coincidence of parallel imports with exchange rate movements, and inferred that price discrimination is an important reason why suppliers of branded products want to block parallel imports.

\section{Price discrimination within a Nation}

Besides price discrimination across nations a monopoly will also price discriminate within a nation if it is able to do so. This sort of pricing structure too is vulnerable to international arbitrage and a possible reason for a supplier to want to block parallel imports. But more than this, as pointed out by Ahmadi and Yang (2000), the market for parallel imports itself may represent a newly segmented market that gives rise to new possibilities for profitable price discrimination. To put it in different words, arbitrage need not result in the full integration of markets for authorized and unauthorized imports of branded merchandise. Government policy regimes that fully allow parallel imports will thus not eliminate price discrimination either across countries or within them.

\section{2-2. Directed Marketing Channels}

We now turn from price discrimination to other regimes under which the suppliers of branded merchandise would wish to block parallel imports. Roughly speaking these are regimes in which manufacturers impose vertical restraints on the distributors of their merchandise either to internalize externalities and lower the costs of marketing, or else as part of a cartel scheme with other manufacturers. Antitrust authorities including the Japan Fair Trade Commission are preoccupied with the latter possibility but almost all of the actual cases exemplify the former one: The vertical restraints are part of an efficient marketing arrangement, not a cartel scheme. That is true of the cases we describe later in the paper. Here we sketch some of the relevant theories.

\section{Inducing efficient investment}

A downstream monopoly, in pursuing its own profit, is inclined to restrict sales. This erodes the combined profit in the marketing channel and so the manufacturer will only ever want to form its downstream distributors as local monopolies if there is some offsetting benefit of its doing so. There are several possible such benefits. One is that a monopoly may have a better incentive to invest than would a competitive industry. Consider a simple example. 
Imagine a two-period example in which the wholesaler's expenditures on advertising, product promotion and quality assurance in period 1 expand the final demand for the product in period 2. If the wholesale industry is a Bertrand duopoly in period 1 then neither firm makes any effort whatsoever at product promotion. If on the other hand there is a monopoly wholesaler that is assured of continuing as a monopolist in period 2, then under plausible conditions it does make some effort in period 1. A manufacturer that confers a monopoly on an independent wholesaler for this reason will also seek to induce optimal pricing by the wholesaler, that is will attempt to forestall the successive monopoly distortion, while preserving the wholesaler's perceived marginal profitability of promotional efforts. For instance it might set its own price to the wholesaler equal to marginal cost and collect a one-time flat fee equal to the discounted present value of the stream of profit in both periods. Additionally, the manufacturer will have to be able to credibly commit itself to maintain the wholesale monopoly in the second period, before the first-period wholesale effort level is chosen. If it cannot do so then vertical integration might be warranted as a way of undertaking efficient promotional investments.

\section{Inducing innovation}

It might seem that wholesaler investments in cost-reducing innovation, as opposed to demand promotion efforts, are less likely to be encouraged by organizing the wholesale industry into a monopoly and indeed are likely to be harmed. This is because of the "replacement effect" sometimes called the "Arrow effect". For the monopoly that innovates, post-innovation profit replaces the preinnovation profit. The competitive firm on the other hand enjoys no profit unless it innovates, so the benefit of an innovation is less to the monopoly than to the competitive firm. But the Demsetz (1969) critique of Arrow on this point is relevant here. That is, the original Arrow (1962) comparison of the benefits of innovation under monopoly and competition presumed that a monopoly would supply less output than the competitive industry. Controlling for the pre-innovation scale of production (scale of demand) reverses the ranking of incentives to innovate. Demsetz argued that the replacement effect was thus an artifact of the scale of the industry in some sense, not an implication of its industrial organization. The point is relevant here because if the manufacturer forms the wholesale industry into a monopoly then it will take steps to counteract any reductions in output this induces. In accord with this, the wholesaler that is a monopoly actually has a greater incentive than a competitive wholesale industry to seek innovation, not less. This could be a contributing reason for a manufacturer to form its wholesale industry into a monopoly.

This is a novel point so we digress briefly to make the argument precisely. Let there be a monopoly with zero manufacturing cost and let there be constant unit cost of distribution/marketing. If manufacturing and distribution are vertically integrated then the added profit to the monopoly in 
each period from an innovation that lowers its unit cost from $\overline{\mathrm{c}}$ to $\underline{\mathrm{c}}$ equals ${ }^{2}$ :

$$
\begin{aligned}
v^{*} & =\int_{\underline{\mathrm{c}}}^{\overline{\mathrm{c}}}(-\mathrm{d} \Pi * / \mathrm{dc}) \mathrm{dc} . \\
& =\int_{\underline{\mathrm{c}}}^{\overline{\mathrm{c}}} \mathrm{D}\left(\mathrm{p}^{*}(\mathrm{c})\right) \mathrm{dc} .
\end{aligned}
$$

Now consider two additional regimes, one in which the monopoly manufacturer deals with a Bertrand industry of identical distributors and the other in which it deals with an independent monopoly distributor. In the case of the Bertrand distributors the manufacturer sets a wholesale price equal to the simple monopoly price minus unit cost of distribution: $\mathrm{w}=\mathrm{p}^{*}(\mathrm{c})-\mathrm{c}$, and attains a first-best outcome. In the case of the monopoly distributor it sets the wholesale price equal to its marginal cost (zero): $\mathrm{w}=0$, and appropriates the profit by a flat fee, again attaining a first-best outcome. But the two situations differ in a way that has so far gone unremarked in the literature on vertical control. They confer differing incentives to innovate on the independent distributors.

For an independent monopoly that purchases at the wholesale price equal to manufacturer marginal cost $(\mathrm{w}=0)$, the benefit from innovation is transparently identical to that of a vertically integrated monopoly. But for the Bertrand industry the benefit is less.

Should only one of the Bertrand distributors introduce the innovation (that lowers its unit cost from $\overline{\mathrm{c}}$ to $\underline{\mathrm{c}})$ it would then set the simple monopoly price given its unit $\operatorname{cost} \mathrm{p}^{*}(\mathrm{w}+\underline{\mathrm{c}})$ if that monopoly price is actually lower than the unit costs of the other firms $\mathrm{w}+\overline{\mathrm{c}}$ (drastic innovation), and otherwise it would price just below the unit cost of the others (nondrastic innovation). In the case of nondrastic innovation $\mathrm{p}^{*}(\mathrm{w}+\underline{\mathrm{c}}) \geq \mathrm{w}+\overline{\mathrm{c}}$, the profit conferred on the Bertrand innovator in each period would be:

$$
\begin{aligned}
v^{\mathrm{c}} & =(\overline{\mathrm{c}}-\underline{\mathrm{c}}) \mathrm{D}\left(\mathrm{p}^{*}(\overline{\mathrm{c}})\right) \\
& <v^{*} .
\end{aligned}
$$

In the case of drastic innovation by a Bertrand competitor $\mathrm{p}^{*}(\mathrm{w}+\underline{\mathrm{c}})<\mathrm{w}+\overline{\mathrm{c}}$, the innovator's

${ }^{2}$ This is from Tirole (1988), p. 391:

$$
\begin{aligned}
\mathrm{d} \Pi^{*} / \mathrm{dc} & =\mathrm{d}\left[\left(\mathrm{p}^{*}-\mathrm{c}\right) \mathrm{D}\left(\mathrm{p}^{*}\right)\right] / \mathrm{dc} \\
& =\partial \Pi / \partial \mathrm{p} \cdot \mathrm{dp}^{*} / \mathrm{dc}+\partial \Pi / \partial \mathrm{c} \\
& =\partial \Pi / \partial \mathrm{c} \\
& =-\mathrm{D}\left(\mathrm{p}^{*}(\mathrm{c})\right)
\end{aligned}
$$


profit in each period equals its own monopoly profit given the wholesale price $\mathrm{w}^{3}$ :

$$
\begin{aligned}
v^{\mathrm{c}} & =\int_{\mathrm{w}+\underline{\mathrm{c}}}^{\infty} \mathrm{D}\left(\mathrm{p}^{*}(\mathrm{c})\right) \mathrm{dc} . \\
& =v^{*}-\int^{\mathrm{c}+\underline{\mathrm{c}}} \mathrm{D}\left(\mathrm{p}^{*}(\mathrm{c})\right) \mathrm{dc}+\int_{\overline{\mathrm{c}}}^{\infty} \mathrm{D}\left(\mathrm{p}^{*}(\mathrm{c})\right) \mathrm{dc} . \\
& =v^{*}-\int^{\mathrm{W}^{+} \underline{\mathrm{c}}} \mathrm{D}\left(\mathrm{p}^{*}(\mathrm{c})\right) \mathrm{dc}+\mathrm{w} \mathrm{D}\left(\mathrm{p}^{*}(\overline{\mathrm{c}})\right) \mathrm{dc} . \\
< & v^{*}
\end{aligned}
$$

For both drastic and nondrastic innovation, the benefit of innovation to the competitive firm is less than the benefit would be to a vertically integrated firm or monopolist: $v^{\mathfrak{c}}<v^{*}$. This is analytically the same argument developed geometrically by Demsetz (1969). The point we draw out here is that organizing the independent distributor as a monopoly rather than a Bertrand competitive industry preserves its incentive to seek cost-reducing innovation.

Our example assumed that the manufacturer precommits to a rule for setting the wholesale price and appropriates the expected profit-including profit from innovation-by means of a one-time flatfee paid at the beginning of the initial period. This can be relaxed slightly without upsetting the fundamental result. Suppose that the terms of trade are renegotiated at the beginning of each period. Then, contrary to the earlier premise, innovation itself will alter the terms of trade. If for example bargaining between the foreign manufacturer and the innovating firm divides their gain from trade with one another equally, then the post-innovation terms of trade would be such that the innovative firm, whether a Bertrand competitor with lower costs than rivals or a sole agent, would garner for itself half the profit. The manufacturer would set its wholesale price w equal to its own marginal cost (zero in the example) but would impose a flat-fee half as great as the profit in that period, not zero as previously supposed. In the initial, pre-innovation period, competition among distributors

${ }^{3}$ The manufacturer (myopically) sets the wholesale price $\mathrm{w}$ to appropriate maximum profit for itself prior to innovation so :

$$
\int_{\bar{c}}^{\infty} \mathrm{D}\left(\mathrm{p}^{*}(\mathrm{c})\right) \mathrm{dc}=\mathrm{wD}\left(\mathrm{p}^{*}(\overline{\mathrm{c}})\right)<\int_{\underline{\mathrm{c}}}^{\mathrm{w}+\underline{\mathrm{c}}} \mathrm{D}\left(\mathrm{p}^{*}(\mathrm{c})\right) \mathrm{dc}
$$

In a more fully developed example the manufacturer would be mindful of the effect of wholesale price $\mathrm{w}$ on incentives to innovate. A higher w causes some innovations to be drastic that would otherwise have been non-drastic, but reduces the gain from innovations that would have been drastic anyway or non-drastic anyway. We ignore these subtleties. 
would enable the manufacturer to fully appropriate the rent; it would set its wholesale price at marginal cost (again zero by assumption) and would impose a flat-fee equal to the expected future stream of profit that the distributors anticipate will be theirs once having innovated and achieved both lower unit cost and an improved bargaining position. The upshot is that the incremental gain from innovation to a Bertrand distributor or a sole agent (i.e. monopoly) distributor are each half as great as in the simpler case just analyzed (with permanent commitment to future wholesale price and flat-fee). The conclusion is the same as before; the monopoly distributor has a larger incentive to innovate than would a Bertrand competitor.

It is necessary for the manufacturer to credibly commit itself to protecting its monopoly distributor from parallel imports in order to truly foster innovation, or to induce distributor investments in promotion. If this is impossible then vertical integration might be warranted. If the manufacturer sets up the monopoly distributor as a wholly owned subsidiary rather than an independent firm then the manufacturer will have a perfect incentive to police parallel imports. Where effective marketing entails resale price maintenance, as we next discuss, no such precommitment is necessary. The manufacturer will have an ongoing incentive to protect its price maintaining distributors from parallel imports.

\section{Resale price maintenance}

Sometimes resale price maintenance is one part of an efficient marketing arrangement. These are manufacturer (or primary wholesaler) stipulated maximum resale prices. One reason for RPM first elaborated by Telser (1960) is to encourage retailers to provide presale demonstrations to customers free of charge. The problem in inducing retailers to provide such special services is that customers may obtain them from one retailer but then buy from another one that offers a lower price. If retailers are not permitted to offer price discounts then customers will have no incentive to buy from any retailer other than the one from whom they obtained the special services. And so minimum resale price stipulations, if enforced, can be effective at preserving the incentive of retailers to provide the presale demonstrations. A manufacturer that organizes this sort of marketing arrangement will have to be vigilant at policing and deterring trans-shipments to price discounters. Inability to stem parallel imports will effectively destroy such a system. There are other ways of informing customers about products but presumably they have higher costs and so the end result of not stemming parallel imports will be a situation in which marketing costs are higher, the quantity supplied is lower and the import price is higher than under a regime of effective resale price maintenance. Paradoxical as it may seem, price discounting ultimately leads to higher prices, not lower ones in this instance.

The promotion of special services is not the only rationale for resale price maintenance. An additional motivation is to prevent revenue-reducing price discounts. This applies to cases in which the quantity produced and shipped to distributors must be determined prior to the realization of uncertain demand. This explanation for RPM was first developed in Flath and Nariu (1989). Also see Flath and Nariu (2000). The essential point is that if the manufacturer has shipped a greater quantity than that which would maximize total sales revenue given the demand, then it is better to destroy some of the good than to sell. The manufacturer could stem this sort of corrosive discounting by (instead of stipulating minimum resale prices) fully compensating the distributors for their returns of unsold merchandise, but then it will not be able to rely upon retailers to determine 
the shipment quantities based on their best private information of the likely demand. By forcing retailers themselves to absorb the losses from unsold merchandise the manufacturer disciplines their shipment orders. Maintaining the price in this regime will also be vulnerable to parallel imports which would ironically enlarge the already glutted supply. This argument applies to one of the cases below, the one involving Nike shoes.

3. Cases Before the Japan Fair Trade Commission Involving Interference with Parallel imports

\section{3-1. Legal Background}

The legal status of private obstruction of parallel imports depends both upon intellectual property law and upon antitrust law. It is widely understood that the intellectual property law of Japan affords mechanisms for the legal obstruction of parallel imports. Specifically, following the 1997 Supreme Court of Japan decision in the Aluminum Wheels case (Jap-Auto Products v. BBS Kraftfarzeug Technik AG, Hanrei Jiho (Supreme Court, July 1, 1997)) it is understood that a patentee and Japanese buyer may legally contract with one another to preclude imports by anyone else if that stipulation is indicated on the patented product itself (the products not sold to the authorized distributor are stamped "not for sale in Japan"). Failing this, the international exhaustion doctrine applies and first sale terminates the patent rights around the world. ${ }^{4}$ The same presumably applies not only to patents but also to trademarks. Thus parties may contract to obstruct parallel imports into Japan, but they will have to police this contract themselves; the government of Japan will not do it for them by confiscating parallel imports at the border for example. This is essentially the regime advocated by Gallini and Hollis (1999), one that allows full latitude for antitrust law to deal with obstruction of parallel imports, possibly on a case-by-case basis according to a rule of reason. But in fact the antitrust law of Japan is currently antagonistic toward all private obstruction of parallel imports, even in instances where such obstruction is probably part of an efficient marketing scheme.

The Antimonopoly and Fair Trade Law of Japan, first enacted in 1947 and significantly amended in 1953, created the Japan Fair Trade Commission, the sole government bureau charged with enforcing the law. ${ }^{5}$ The JFTC investigates possible violations, issues warnings, holds hearings and issues decisions that may be appealed through the courts. There are three kinds of decisions: recommendation decisions, consent decisions and formal decisions. All are published in the compilation of cases of the JFTC. Recommendation decisions come about when the JFTC has found a violation and the respondent has agreed to remedial action without recourse to a formal hearing.

${ }^{4}$ Under the doctrine of international exhaustion, the patent or trademark owner exhausts its intellectual property right upon the first sale, and retains no authority to limit or interfere with subsequent resale of the item, including international resale. Under the national exhaustion doctrine the trademark owner does retain the authority to limit subsequent international sale but not subsequent domestic resale of the item; it exhausts its intellectual property domestically but not internationally upon the first sale of the item. See Maskus (2000).

${ }^{5}$ For a brief overview of the antimonopoly law of Japan refer to Matsushita (1997). 
A consent decision results from a formal hearing in which the JFTC has found a violation and the respondent has agreed to take remedial action and not appeal the decision through the courts. A formal decision is issued after a formal hearing has either determined that no violation has occurred, or else has determined that a violation has occurred and orders cessation of the offending activities, which the respondent may appeal to the Tokyo High Court and then the Supreme Court of Japan.

The JFTC official stance toward parallel imports is generally disapproving, as detailed in its "Guidelines Concerning Distribution Systems and Business Practices" (July 11, 1991). Obstruction of parallel imports, if it is conducted to maintain the price level of the product covered by a sole distributorship contract-and not say to prevent consumer misunderstanding due to differing product specifications or to protect consumer health or safety caused by deterioration of quality-presents a problem under the antimonopoly act, section 19 which reads in its entirety "No entrepreneur shall employ unfair trade practices." As defined in section 2 of the act, "unfair trade practices" are among a list published by the JFTC (notification no. 15) and revised by it from time to time, most recently in June 18, 1982. The list includes, among other things, exclusive dealing (11), resale price restrictions (12), dealing on restrictive terms (13), and interference with a competitor's transactions (15). ${ }^{6}$ Obstruction of parallel imports is generally classified as an instance of the last of these just listed, interference with a competitor's transactions.

Sole distributor contracts in which a foreign supplier designates a Japanese firm as the only authorized distributor of its products in Japan are allowed in many instances, according to the JFTC guidelines. Such contracts may present a problem if the sole distributor itself manufactures or markets similar products as the supplier and has a market share of $25 \%$ or more or is ranked first, or if the supplier has a market share of $10 \%$ or more or is ranked third or higher. But, again according to the JFTC guidelines, a sole distributor contract does not present a problem if it is for the purpose of newly selling a product and is for a short-term (3 to 5 years), or if the sole importer has a market share of $10 \%$ or less or is ranked fourth or lower. Stipulations of a sole distributor contract such as that the sole distributor enforce or abide by RPM, exclusive dealing, customer assignments, exclusive territories and so on, are subject to the same guidance as if they pertained to contracts between a domestic supplier and its distributors. Resale price maintenance is in principle illegal according to the JFTC guidelines but a recent case on appeal to the Supreme Court of Japan (JFTC compilation of cases vol. 45, p. 461, December 12, 1998) seemed to uphold the legality of resale price maintenance in marketing systems involving presale customer interviews. ${ }^{7}$ That is the court recognized the Telser special services argument as a valid defense of resale price maintenance. But in a subsequent case (the JFTC warning to Max Factor, June 27, 2001) the JFTC has argued that it is still illegal to enforce minimum resale price stipulations on retailers who do not provide presale

${ }^{6}$ The text of the antimonopoly law and the list of unfair trade practices are posted on the JFTC web site, both in Japanese and in English translation, as are the JFTC guidelines. http://jftc.go.jp

${ }^{7}$ For a synopsis and analysis of this case involving the cosmetic company Shiseido refer to Taylor (2000). 
customer interviews. ${ }^{8}$ In other words the manufacturer may not interfere with price discounting by unauthorized free-riders. If this is so then the per se illegality of resale price maintenance is largely intact. Vertical nonprice restraints such as exclusive dealing, customer assignments or exclusive territories may be allowed if the manufacturer is not influential in the market (for instance has a market share less than $10 \%$ or a rank of fourth or lower or is a newly entered firm). With these caveats, a foreign supplier often may designate a Japanese company as its sole authorized distributor in Japan, but it may not in any way obstruct imports of genuine goods by unauthorized distributors.

Having now discussed the relevant theories and laws we turn to some actual cases.

\section{3-2. The Cases}

\section{water purification devices ${ }^{9}$}

This case involves interference with parallel imports of "Seagull" brand water purification devices of the sort that attach to household faucets, by GrandDukes k.k., since 1991 the sole authorized importer in Japan of the products in question, produced by General Ecology Inc. based in Pennsylvania, USA. In 1994 unauthorized parallel imports had forced GrandDukes to lower its prices of Seagull IV products and it requested General Ecology suspend shipments to the offender. From inspection of serial numbers at the Shinjuku (Tokyo) retail store which GrandDukes reported to General Ecology the source was traced to a wholesaler in Massachussets and in 1995 GE ordered the wholesaler to cease its unauthorized sales in Japan. But then a similar incident occurred in 1997 when the same Shinjuku retailer was found to have obtained unauthorized shipments from a wholesaler in Wisconsin which led GE to suspend shipments to it. And also in 1997 a wholesaler in California was traced as the source of other shipments and ordered by GE to cease its sales in Japan. Although GrandDukes' share of market sales in Japan of water purification devices was a mere 2 percent, the products of General Ecology were known in Japan from being featured on a popular TV show in which celebrities compete against one another in cook-offs. GrandDukes is itself a primary wholesaler at the head of an elaborate marketing channel involving secondary wholesalers and retailers. There is some suggestion that GrandDukes sought to maintain resale prices, which were substantially above the US prices of the same products. From the web site of General Ecology:"GrandDukes Corporation is the ONLY authorized distributor of General Ecology products in Japan.... Please note that Japanese plumbing is different from plumbing in the United States. We recommend to all of our Japanese customers that they purchase their purifiers in Japan to ensure proper configuration and to receive GrandDukes excellent customer care and warranty service." In other words there is some suggestion that special services and after-sale service are important in marketing these products, entailing not only vertical restraints but also investment and possibly even innovation. The JFTC found that GrandDukes' connivance with General Ecology to interfere with parallel imports violated the antimonopoly law section 19 (unfair business practice), general designation clause 15 (interference with competitors' transactions), and it issued a recommendation decision in June 23, 1998 (accepted on July 1998).

\footnotetext{
${ }^{8}$ The JFTC warning to Max Factor is discussed by Iijima (2001).
}

${ }^{9}$ This case is discussed by Maeda and Ueda (1999). 
This case exemplifies the conjunction of just about all of the economic arguments related earlier. There is a strong suggestion of pricing to market, i.e. non-pass-through of the mid-1990's appreciation of the yen relative to the dollar, in the facts that the market share in Japan was a mere 2 percent and yet prices of the products were substantially higher in Japan than in the US. International price discrimination of this sort need not have been the sole rationale for blocking parallel imports; the preservation of incentives to invest and innovate may also have played a role here. This makes it impossible to say whether the JFTC action to promote parallel imports was beneficial to Japan or harmful in this particular case.

\section{Herend chinaware ${ }^{10}$}

This case involves the products of Herend Porcelain Manufactury Ltd. located in Hungary, the famous porcelain supplier to the royal Hapsburgs, still manufactured in Herend, Hungary and exported to twenty or more countries across Europe, America and Japan where the Herend Rose pattern, Indian floral, and Aponee green pattern chinaware are in great demand. Hoshi Shoji K. K. based in Nagoya, has been from its founding in the 1970's the sole import agent in Japan for Herend chinaware, which it sells through department stores and upscale specialty super stores. In fall 1992 unauthorized parallel imports were advertised in newspapers and fliers for sale at discount prices-30 percent below the prices stipulated by Hoshi. This led Hoshi in 1993 by checking the serial numbers and reporting them to the manufacturer to seek foreclosure of the unauthorized source which turned out to be the sole agent in Hong Kong. A later similar incident occurred in 1999 involving parallel imports from Australia sold at prices 30 percent to 40 percent below standard and which was also shut off by Herend at the request of Hoshi the following year 2000. In fact Herend had previously suspended all shipments to its sole agent in Australia for three years 1995-7 because of its earlier unauthorized sales to Japan. In 1994 a retailer in Hiroshima had been selling the chinaware at a 40 percent discount. Hoshi had checked the serial numbers and traced the source to Herend's sole agent in France and as a result its own shipments were suspended for three years by Herend. Also in 1994 a retailer in Tokyo was selling at half price and advertising these prices in the newspaper, its source the sole Herend agent in Italy which led to a warning from Herend (not a suspension of shipments). Hoshi had not adjusted its preferred retail prices in light of the strengthening yen in the mid 1990's. Thus the price outside Japan became significantly lower than the price in Japan. The JFTC found that Hoshi's interference with parallel imports violated the antimonopoly law section 19 (unfair business practice), general designation clause 15 (interference with competitors' transactions), and it issued a recommendation decision on February 2, 1996 (accepted March 22, 1996).

There may be more to this case than simple price discrimination across nations-although that is clearly present as indicated by Herend's non-pass-through of exchange rate movements. Hoshi has made significant investments including its sponsoring of special exhibits of Herend porcelain and demonstrations of its manufacture by artisans at department stores and elsewhere. Additionally it solicits patterns specially designed for the Japanese market; that is it conveys information to the manufacturer valuable for its sales in Japan. The JFTC action jeopardizes the incentive of Herend's sole agent Hoshi in making these sorts of efforts.

\footnotetext{
${ }^{10}$ See Arai, Itou and Ishimoto (1996).
} 


\section{Steinway pianos $^{11}$}

The Japan based k. k. Matsuo Gakki (Matsuo musical instruments) was the sole import agent in Japan for the sale of Steinway pianos produced by Steinway and Sons, Hamburg, Germany, a branch of the US manufacturer and the sole authorized producer-supplier of the product outside of North and South America. In 1988 a public hall in Hiroshima prefecture obtained a Steinway piano from the sole distributor in Holland, which Matsuo was able to deduce by checking the serial number on the instrument. There was a similar instance pertaining to three pianos at a public hall in Nagoya in 1990, and still other instances in Kyoto-to, Uji in 1993 and in Shizuoka. In 1995 this information led Steinway Hamburg to cease shipments to a dealer in Germany that had been the source of one of the unauthorized sales in Japan. The price in Japan charged by Matsuo was 1.4 times as great as the price in Germany of the same pianos. The unauthorized parallel imports were at prices 10 percent to 20 percent less than those of Matsuo. Matsuo's sales of Steinway pianos in 1994 amounted to about 1.6 billion yen (around \$16 million). The JFTC found that Matsuo Gakki's interference with parallel imports violated the antimonopoly law section 19 (unfair business practice), general designation clause 15 (interference with competitors' transactions), and it issued a recommendation decision on April 5, 1996 (accepted May 8, 1996).

There is little here to suggest any motive for blocking parallel imports other than to price discriminate, both across nations and possibly also within Japan by for example charging more to public halls than to private demanders.

\section{Nike Japan Corp. ${ }^{12}$}

This case involves resale price maintenance and interference with parallel imports of Nike brand sports shoes, which include running shoes and shoes for specific categories of sport including basketball, tennis, soccer, baseball, rugby, golf, etc. Nike Japan, as the agent in Japan for Nike Inc. (of the US), contracts with manufacturers in Southeast Asia for importation and distribution of shoes through wholesale agents to sporting goods stores, shoe stores and other retailers. Retailers of the shoes are categorized by Nike Japan and in particular those it considers "key accounts" are explicitly identified as such. These receive priority in shipments of the top models. The key accounts are invited to four seasonal sales meetings each year but the general account retailers to only two. Nike Japan enforced and elicited the aid of wholesalers in enforcing their desired retail prices, disallowed parallel imports, and disallowed newspaper advertising of price discounts on the shoes. In 1995 the Airmax and AirJordan shoes of Nike became extremely popular in Japan and Nike's market share increased. The top models came to be reserved for the key account retailers. Nike Japan cut off shipments to retailers that violated its retail price stipulations or proscriptions against parallel imports and discount advertising. These stipulations were particularly difficult to enforce late in each sales season when retailers with excess inventory were apt to deeply discount their prices. Elevation of prices above the stipulated level during the Nike boom was not regarded as a problem by Nike Japan so it is clear that their stipulation was a minimum retail price, that is a price floor. The JFTC

\footnotetext{
${ }^{11}$ See Senba (1996).

${ }^{12}$ See Yamaguchi (1998).
} 
found that Nike Japan's resale price maintenance violated the antimonopoly law section 19 (unfair business practice), general designation clause 12 (resale price maintenance) and it issued a recommendation decision on June 29, 1998 (accepted July 28, 1998). An investigation by the JFTC in November 1997 found ample instances of price discounting, advertising of price discounts, and distribution through discount outlets suggesting that Nike Japan had already ceased its offending practices.

This is an example of RPM to maintain sales revenue in the face of uncertain demand. The social welfare implications of this practice are unfathomable in the most general setting analyzed by Deneckere et al (1997), but are straightforward in the constant unit cost, two-state, multiplicative linear demand case analyzed by Flath and Nariu (2000). There, if in the absence of price maintenance the price would actually fall to zero in the low demand state, then privately profitable price maintenance erodes social welfare. In all other instances in the Flath and Nariu example it enhances social welfare. The Flath and Nariu example is also helpful in understanding the conditions in which this explanation for RPM applies: Low unit costs in relation to the intercept of the demand curve, low probability of realization of the low demand state, and great variation between the low demand state and high demand state all favor price maintenance in low demand states. Minimum price stipulations that are merely to curb price discounting in low demand states are more likely to be profitable if low demand is less likely. The fact that Nike shoes were popular and heavily advertised suggests a high price cost-margin (and low unit cost relative to demand intercept). The seasonality of demand imparts an element of demand uncertainty that is crucial to the explanation. The fact that shoes can be held in inventory for later sale is one reason for Nike to prefer resale price maintenance over acceptance of returns of unsold merchandise. Preserving incentives for retailers to base orders on their private information regarding the local demand is another. It seems that the JFTC interference with price maintenance by Nike Japan will probably erode Japanese welfare by reducing the supply and raising the price of Nike shoes in Japan. Although Nike Japan disallowed parallel imports this case uncovered no instances in which the company took specific actions to enforce this stipulation. Parallel imports could have preempted Nike Japan's ability to maintain retail prices but apparently did not. It took an injunction from the JFTC to do it.

\section{Yashiro $^{13}$}

This case involves interference with parallel imports of ladies' handbags and other such leather goods produced by Groom Distribution S.A.L.L. of Paris, France. About 60 percent of Groom's output it exports and half of that exports to Japan. Yashiro k.k. based in Osaka in 1989 became the first to sell Groom products in Japan, ordering ladies' handbags, wallets, and briefcases, from an agent of Groom in Japan Yadai Shoji kk. and selling them to department stores in Japan. Soon thereafter Fuji Sankei Living Service began purchasing such handbags directly from Groom and undertaking catalogue sales in Japan. Yashiro requested that Groom suspend shipments to Fuji Sankei. Although Yashiro was at first the only seller of Groom products in Japan it did not have a sole agent contract with Groom. Fuji Sankei was selling handbags, jewelry, leather goods by catalogue "Collection i". Fuji sankei held few inventories itself, ordering the bags directly from

\footnotetext{
${ }^{13}$ See Abe and Fujihara (1990).
} 
Groom upon receiving a customer order. At current exchange rates the retail prices of the bags sold by Yashiro at 49,440 yen were 1.7 times the prices in Paris (=28,600 yen; 1,300 Francs). Fuji sankei which was selling through its fall 1989 catalogue at essentially the Paris retail price (28,840 yen) and greatly eroding sales by Yashiro through department stores. In August 1989 Yashiro had Yadai Shoji request that Groom suspend shipments to Fuji Sankei. Groom complied with the request but then Groom entered a contract with Fuji Sankei in 1990 stipulating retail price. For this Groom received a warning from JFTC, in essence voiding the resale price stipulation. The JFTC found that Yashiro's interference with parallel imports violated the antimonopoly law section 19 (unfair business practice), general designation clause 15 (interference with competitors' transactions), and it issued a recommendation decision on July 11, 1990 (accepted September 5, 1990).

Here is an instance in which interference with parallel imports was arguably to preserve incentives to invest. By selling the handbags through department stores, Yashiro was credibly certifying the quality of this little known, newly entered brand. Fuji Sankei by selling similar handbags through its catalogue was free-riding on the promotional investments of Yashiro. Groom itself seems to have belatedly realized its own interest in protecting Yashiro's incentives to invest but was pre-empted from doing anything about it by the JFTC decision in the case.

\section{Hobby Japan/ Magic, the Gathering ${ }^{14}$}

Hobby Japan was the sole agent in Japan of Wizards of the Coast, based in Seattle, USA, the producer of the highly successful trading card game "Magic: the Gathering", introduced in August 1993 in the US and eventually seven other countries. Besides distributing the orginal English language version of the game, Hobby Japan was also the sole producer of the Japanese language version of the game. Hobby Japan sought to block parallel imports of the cards and sought also to maintain prices in Japan and ran afoul of the JFTC. By 1996 there were about 10 varieties of such games in Japan competing with Magic. The market-wide sales in Japan of all such cards reached 7 billion yen in Japan in 1996. Book stores, novelty stores, personal computer shops, and so on were registered by Hobby Japan as official authorized retailers. In 1995 parallel imports of the English language version Magic cards for sale at discount prices became a problem, and in November 1995 Hobby Japan initiated steps to suspend its own shipments to any dealers handling parallel imports. From January 1996 Wizards entered contracts with its North American distributors barring their sales either to other wholesalers or to anyone outside North America. The import price of the cards in Japan rose shortly after this. Hobby Japan introduced the Japanese version in 1997 at a stipulated retail price of 1420 yen for a 60 card basic starter pack (and stipulated a price of 1380 yen for the English version). From April 1996 to January 1997 Hobby Japan had investigated retailers and wholesalers to uncover instances of parallel imports. Offending dealers were denied shipments of the Japanese language version of the trading cards. Hobby Japan supported the game by sponsoring conventions to promote interest in the game. The JFTC found that Hobby Japan's resale price maintenance and its suspension of shipments to price discounters violated the antimonopoly law section 19 (unfair business practice), general designation clause 12 (RPM) and 13 (obstruction of transactions) and issued a recommendation on Oct 22, 1997 (accepted November 28, 1997). The

\footnotetext{
${ }^{14}$ See Ikeda and Suzuki (1998).
} 
JFTC also issued a warning to Hobby Japan about illegal interference with parallel imports.

One curious aspect of this case is the fact that an active internet based auction market for individual cards had developed in the US by 1994 (analyzed by Lucking-Reily (1999) from the standpoint of the economic theory of auction pricing). Such a second-hand market either seems not to have evolved in Japan or else did not interfere with price maintenance in the primary market. But what can have led Hobby Japan to want to maintain resale prices in the first place? The Telser special services argument possibly applies here. When the game was first introduced its novelty and inherent complexity posed a serious marketing problem. Retailers who understood the game well enough to explain it to the potential customers were possibly essential to its initial success ${ }^{15}$, but subject to free-riding. Also Hobby Japan's sponsorship of conventions indicates that promotional investment was valuable here. Its success ultimately led to innovation. The trading card game Pokemon with tie-ins to animated television shows was developed by Hobby Japan. It then licensed Wizards of the Coast to distribute the game in the US and they both profited greatly.

\section{Hägen-Dazs ${ }^{16}$}

This case involves resale price maintenance and obstruction of parallel imports of ice cream. Hägen-Dazs Japan ( HDJ), a subsidiary of the US company Pillsbury, both produces ice cream in Japan and also imports it. It has been successful, is a familiar brand in Japan, and has attained a greater than 10 percent market share of sales in Japan of premium ice cream (but a much smaller share of sales all ice cream). HDJ along with its agent wholesalers enforced a system of minimum retail prices on sales of its ice cream. It dispatched a so-called "sales lady" to make the rounds of retailers and communicate price stipulations as well as to monitor compliance. In the event of a violation HDJ suspended shipments of popular flavors, and if violations persisted, suspended shipments of all flavors to the offending retailer. In 1994 HDJ detected unauthorized parallel imports which were being sold at 30 percent discount below their own stipulated retail price. They traced the imports to the source which turned out to be wholesalers in the US, by checking the lot numbers on the imported products. Pillsbury had introduced the lot number system in 1990 precisely to monitor such violations. In 1995 Pillsbury cut off shipments to the offending US wholesalers, including one in Washington state, two in California and still others. In June 1996 the JFTC initiated proceedings in the matter and ordered a cessation of HDJ interference with parallel imports. The JFTC found that Hägen-Dazs Japan's resale price maintenance and its interference with parallel imports violated the antimonopoly law section 19 (unfair business practice), general designation clause 12 (rpm) and 15 (interference with competitors' transactions), and it issued a recommendation decision on March 3, 1997 (accepted April 4, 1997).

It seems that the obstruction of parallel imports was linked to the system of resale price maintenance. But why did HDJ wish to maintain resale prices? And why did it wish to maintain them at levels 30 percent or more above the price in the US? On the latter question, international

\footnotetext{
${ }^{15}$ The game resembles the famously complex role-playing game Dungeons and Dragons (" $\mathrm{D}$ and D" to the fanatics).

${ }^{16}$ See Ishimoto and Komuro (1997).
} 
price discrimination is a plausible explanation. As in some of the other cases we have discussed, the problem of parallel imports seems to have coincided with years in which the yen had appreciated significantly (relative to the US dollar). Perhaps the RPM within Japan was part of a system of price discrimination across venues or regions within the country, but this is only a guess.

\section{Conclusion}

This paper has made a modest contribution to the economic theory of sole distributorship contracts, and has applied that and other theories to some recent Japanese antimonopoly cases involving private obstructions of parallel imports. Our contribution to the theory of sole distributorship contracts is to show that a distributor that is a monopoly actually has a stronger economic incentive to seek cost-reducing innovation than would an industry of Bertrand competitors. This is a novel application of the Demsetz (1969) counterexample to the Arrow replacement effect.

Our main focus is upon some antimonopoly cases in Japan concerning private interference with parallel imports. There are many reasons why manufacturers of trademarked goods might wish to limit imports of their merchandise to distributors designated by them and obstruct imports by others. One reason is to prevent arbitrage from upsetting profitable international price discrimination. There are plenty of examples in which manufacturers do not fully pass-through exchange rate movements to import prices. And these instances do coincide with actual attempts to obstruct parallel imports, as in a number of cases discussed here including those involving Seagull brand water purifiers, Herend chinaware, Steinway pianos, and Hägen-Dazs ice cream. To the extent price discrimination of this sort is the motive, government policies that promote parallel imports will lower prices in the importing country and enhance its economic welfare. But even in the cases just mentioned price discrimination seems not to have been the only reason why the manufacturers attempted to interfere with parallel imports. The other reasons include the improved incentives to invest and innovate of a monopoly distributor over those of a competitive industry of distributors, and to preserve an efficient marketing system that depends upon a system of resale price maintenance. 


\section{References}

Abe, Kinichi and Yuuji Fujihara (1990). Kabushiki kaisha yashiro-ra no dokusen kinshi hou ihan jiken (The case of violations of antimonopoly law by Yashiro et al), Kousei Torihiki, no. 480 (1990.10), pp. 52-55.

Ahmadi, Reza and Rachel B. Yang (2000). "Parallel Imports: Challenges from Unauthorized Distribution Channels," Marketing Science, vol. 19, no. 3 (Summer), pp. 279-294.

Arai, Toshio; Taketoshi Itou, and Masayuki Ishimoto (1996). You shokki yunyuu sou dairi ten ni yoru heikou yunyuu futou sogai jiken (The case of unfair obstruction of parallel imports by a sole import agent for western tableware), Kousei Torihiki, no. 548 (1996.6), pp. 62-66.

Arrow, Kenneth (1962). "Economic Welfare and the Allocation of Resources for Inventions," in R. Nelson, ed., The Rate and Direction of Inventive Activity, Princeton University Press.

Demsetz, Harold (1969), "Information and Efficiency: Another Viewpoint ," Journal of Law and Economics v. 12, no. 1 (Apr) pp. 1-22.

Deneckere, Raymond, Howard P. Marvel, and James Peck (1997). "Demand Uncertainty and Price Maintenance: Markdowns as Destructive Competition," American Economic Review, vol. 87 no. 4 (September), pp. 619-641.

Flath, David (2002). "Distribution Keiretsu, FDI and Import Penetration in Japan," unpublished manuscript.

Flath, David (1989). "Vertical Restraints in Japan," Japan and the World Economy, 1: 187-203.

Flath, David and Tatsuhiko Nariu (2000). "Demand Uncertainty and Resale Price Maintenance," Contemporary Economic Policy, vol. 18, no. 4, pp. 397-403.

Flath, David and Tatsuhiko Nariu (1989). "Returns Policy in the Japanese Marketing System," Journal of the Japanese and International Economies, 3: 49-63.

Gallini, Nancy T. and Aidan Hollis (1999). "A Contractual Approach to the Gray Market," International Review of Law and Economics, vol. 19, pp. 1-21.

Ikeda, Shinya and Naomi Suzuki (1998). Kabushiki kaisha hobii japan no dokusen kinshi hou ihan jiken ni tsuite (Regarding the case of antimonopoly law violation by Hobby Japan K. K.), Kousei Torihiki, no. 568 (1998.2), pp. 75-78. 
Ishimoto, Masayuki and Naohiko Komuro (1997). Haagendattsu japan kabushiki kaisha no dokusen kinshi hou ihan jiken (Violation of antimonopoly law by Häagen-Dazs Japan, Inc.), Kousei Torihiki, no. 562 (1997.8), pp. 74-79.

Japan Fair Trade Commission (1991). "Guidelines Concerning Distribution Systems and Business Practices," (July 11, 1991), posted on the JFTC web site.

Lucking-Reily, David (1999). "Using Field Experiments to Test Equivalence Between Auction Formats: Magic on the Internet," American Economic Review, vol. 80 no. 5 (Dec.), pp. 1063-1080.

Maeda, Yoshinori and Mitsuhiro Ueda (1999). Joussuiki yunyuu sou dairi ten ni yoru heikou yunyuu futou bougai jiken ni tsuite (Regarding the case of unfair hindrance of parallel imports by a sole import agent for a water purification system), Kousei Torihiki, no. 579 (1999.1), pp. 71-75.

Malueg, David A. and Marius Schwartz (1994). "Parallel Imports, Demand Dispersion, and International Price Discrimination," Journal of International Economics, vol. 37, pp. 167195.

Maskus, Keith E. (2000). "Parallel Imports,” World Economy, vol. 23, no. 9 (September), pp. 1269-84.

Maskus, Keith E., and Yongmin Chen (2002). "Vertical Price Control and Parallel Imports," Review of International Economics, forthcoming.

Matsushita, Mitsuo (1997). "The Antimonopoly Law of Japan”, Ch. 5 in Edward M. Graham and J. David Richardson, eds., Global Competition Policy, Institute of International Economics, pp. 151-197.

Rey, Patrick and Jean Tirole (1986). "The Logic of Vertical Restraints", American Economic Review", pp. 221-233.

Richardson, Martin (2002). "An Elementary Proposition Concerning Parallel Imports," Journal of International Economics, vol. 56, pp. 233-245.

Schmalensee, Richard (1981). "Output and Welfare Implications of Third-Degree Price Discrimination”, American Economic Review", vol. 71, issue 1 (March), pp. 221-233.

Senba, Tadao (1996). Piano yunyuu sou dairi ten ni yoru heikou yunyuu futou sogai jiken ni tsuite (Regarding unfair obstruction of parallel imports by a sole import agent for pianos), Kousei Torihiki, no. 552 (1996.10), pp. 52-55. 
Stigler, George (1987). The Theory of Price, MacMillan, fifth edition.

Taylor, Veronica (2000). "Re-Regulating Japanese Transactions: The Competition Law Dimension", ICCLP Review (International Center for Comparative Law and Politics, Graduate School of Law and Politics, University of Tokyo), vol. 3, no. 2 (September), pp. $16-29$.

Telser, Lester (1960). "Why Should Manufacturers Want Fair Trade?" The Journal of Law and Economics, vol. 3, pp. 86-105.

Tirole, Jean (1988). The Theory of Industrial Organization, MIT Press.

Yamaguchi, Yuki (1998). Kabushiki kaisha naiki japan no dokusen kinshi hou ihan jiken (The case of antimonopoly law violation by Nike Japan Corp.), Kousei Torihiki, no. 577 (1998.11), pp. 82-87. 